\title{
A neonate with molybdenum cofactor deficiency type B
}

\author{
Yuanyuan Lin, Yanli Liu, Si Chen, Jianghu Zhu, Yumei Huang, Zhenlang Lin, Shangqin Chen \\ Department of Neonatology, The Second Affiliated Hospital \& Yuying Children's Hospital, Wenzhou Medical University, Wenzhou, China \\ Correspondence to: Shangqin Chen. Department of Neonatology, The Second Affiliated Hospital \& Yuying Children's Hospital, Wenzhou Medical \\ University, 109 Xueyuan West Road, Lucheng District, Wenzhou 325000, China. Email: csq5725@126.com.
}

\begin{abstract}
Molybdenum cofactor deficiency (MoCD) is an autosomal recessive disease which leads to a combined deficiency of molybdenum cofactor dependent enzymes. There are four different genes in molybdenum cofactor biosynthesis, MOCS1, MOCS2, MOCS3, GEPH. The patients with MOCS2 homozygous mutation who onset in the neonatal period always have severe seizures, feeding difficulties, progressive neurological deterioration. The incidence of the disease is low, and certain types have never been reported in China. Here, we present a Chinese term infant with MOCS2 who presented seizure, intolerance to feed and hypotonia on the third day after birth. Treatment included intravenous nutrition, antibiotic, and anticonvulsant therapy. The seizure can't be controlled and her encephalopathy progressed. A homozygous mutation in exon 4 in MOSC2 gene was found and the mutation of the patient has not been reported before. In conclusion, the patients with MOCS2 who onset in neonatal period often shows uncontrolled seizure, feeding difficulties, hypotonia and early death. And the MRI of them shows severe encephalomalacia. There is no treatment for the disease by now, but early diagnosis and genetic detection can give the family genetic counseling.
\end{abstract}

Keywords: MOCS2; neonate; seizures; encephalomalacia

Submitted Oct 31, 2020. Accepted for publication Feb 27, 2021.

doi: $10.21037 / \mathrm{tp}-20-357$

View this article at: http://dx.doi.org/10.21037/tp-20-357

\section{Introduction}

Molybdenum cofactor deficiency (MoCD) is an autosomal recessive disorder, which causes the combined deficiency of molybdenum-dependent enzymes, including sulfite oxidase, xanthine dehydrogenase, and aldehyde oxidase (1). More than $50 \%$ of the patients have MOCS1 mutations, followed by MOCS2, only one patient has been described with MOCS3 gene mutation (2). So far two families are reported have GEPH mutations (3). Accumulation of toxic levels of sulfite oxidase maybe the main pathogenic mechanism for the neurological dysfunction.

All patients with MOCS2 who develop symptoms in the newborn period have typical clinical feature: refractory seizures, neurological deterioration, facial dysmorphism, feeding difficulties and early death (4).

We present the following case in accordance with the CARE reporting checklist (5) (available at http://dx.doi. org/10.21037/tp-20-357).

\section{Case presentation}

A female Chinese infant weighing 3,960 g was born after $39+3$ week's gestation to a 27 -year-old primigravida mother by cesarean section. The amniotic fluid was clear and there were no abnormalities with umbilical cord or placenta. The Apgar scores of the baby were 9 at $1 \mathrm{~min}$ and 10 at $5 \mathrm{~min}$. She was the first baby of an unconsanguineous family. There was nothing special about the family history. The girl was well until the third day after birth, when she showed feeding difficulties, strenuous breathing, and refractory convulsions. The local hospital started intravenous nutrition, intubation and mechanical ventilation, antibiotics, and anticonvulsant therapy, while the seizures still couldn't be controlled. The cerebrospinal fluid was normal. One the third day of life, she had a brain MRI which showed low-density signal around the lateral ventricle (Figure 1). Then the patient was transferred to our hospital. She had dystonia and loss of reflexes when 

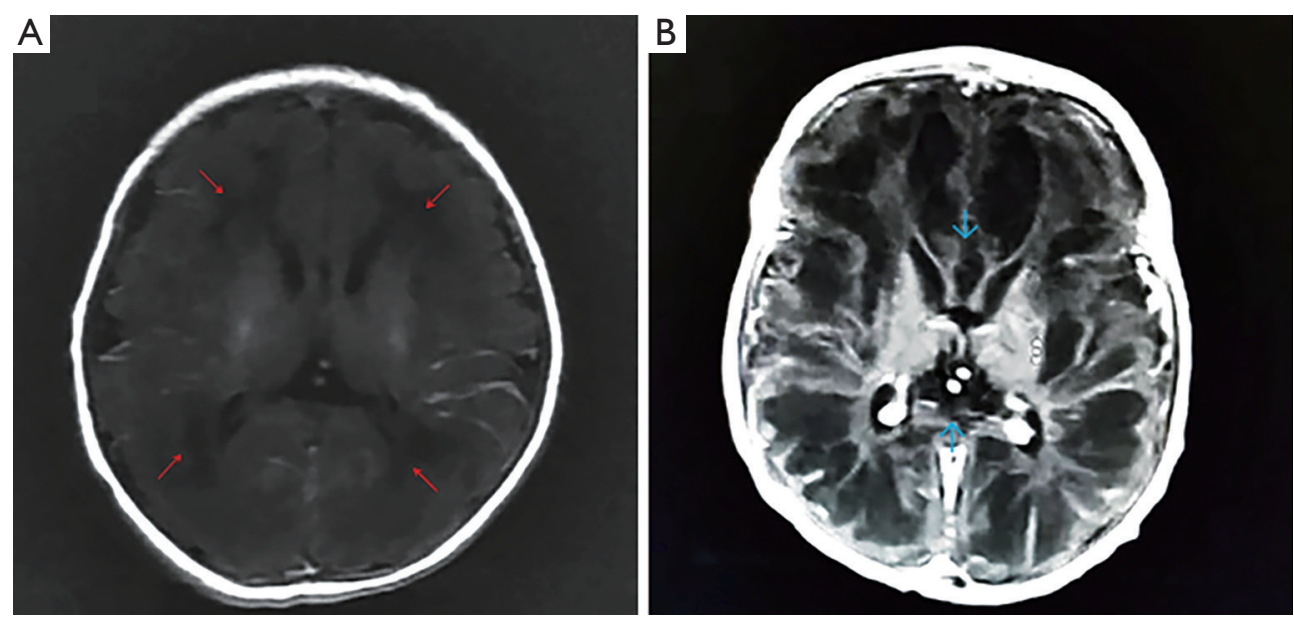

Figure 1 Axial T1-weighted image of brain MRI. (A) At age 3 days from local hospital: there were hypointensity signals around the lateral ventricle (red arrows). (B) At age 23 days from Shanghai: there were symmetric subcortical cystic encephalomalacia and agenesis of the corpus callosum (blue arrows).

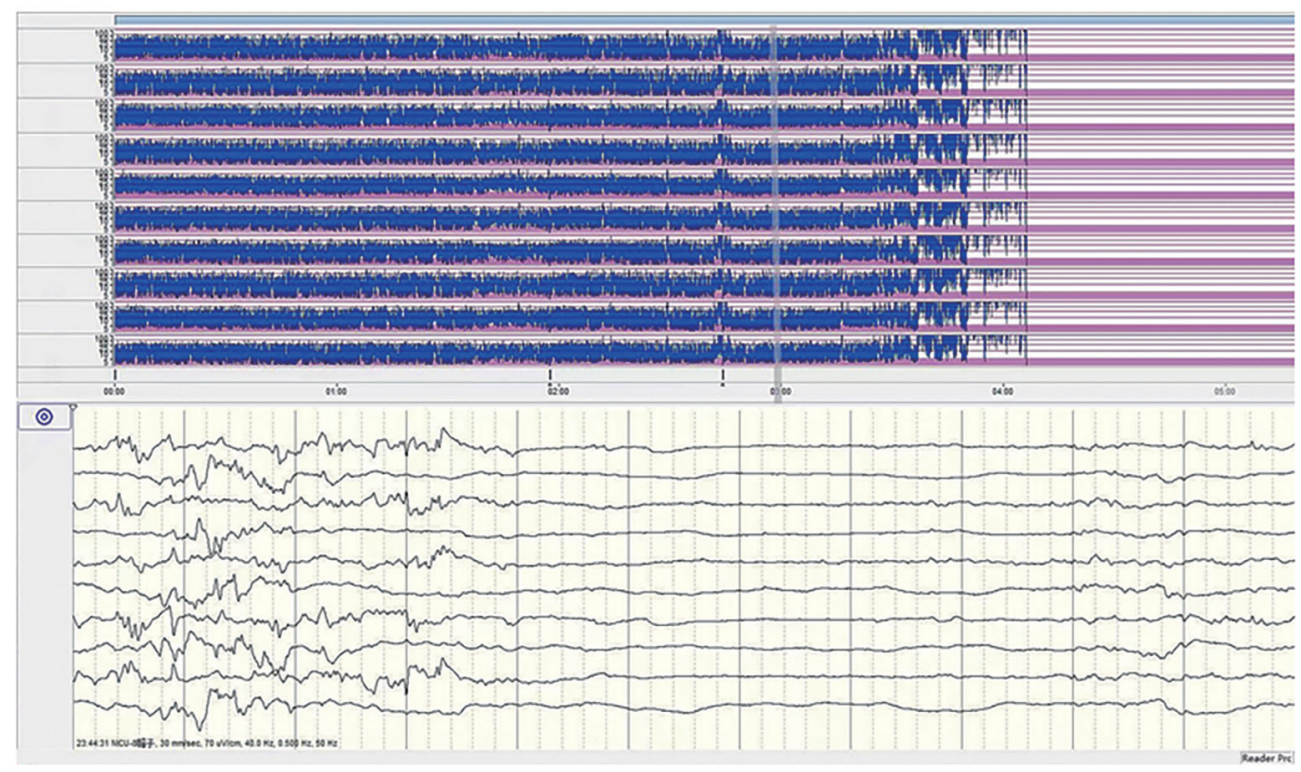

Figure 2 The EEG of age 13 days from local hospital: the background activity was burst suppression, the duration of the outbreak period was about 4-9 seconds, and the duration of the inhibition period was about 5-11 seconds.

she hospitalized while no dysmorphic features were noted. During the period of hospitalization, we found the serum uric acid was undetectable. The electroencephalogram was abnormal. The background activity was burst suppression, the duration of the outbreak period was about 4-9 seconds, and the duration of the inhibition period was about $5-11$ seconds (Figure 2). There were no abnormalities in other organs and metabolic investigation of blood and urine samples was normal too. The blood fluid culture, TORCH examination was also negative, that ruled out infection. The parents decided to sign off and went to Shanghai for further treatment after 5 days. At the age of 23-day, the MRI (from Shanghai) revealed symmetric white matter multicyclic changes (Figure 3). We performed a genetic whole exon test on this infant and her parents. We found a homozygous mutation at exon 

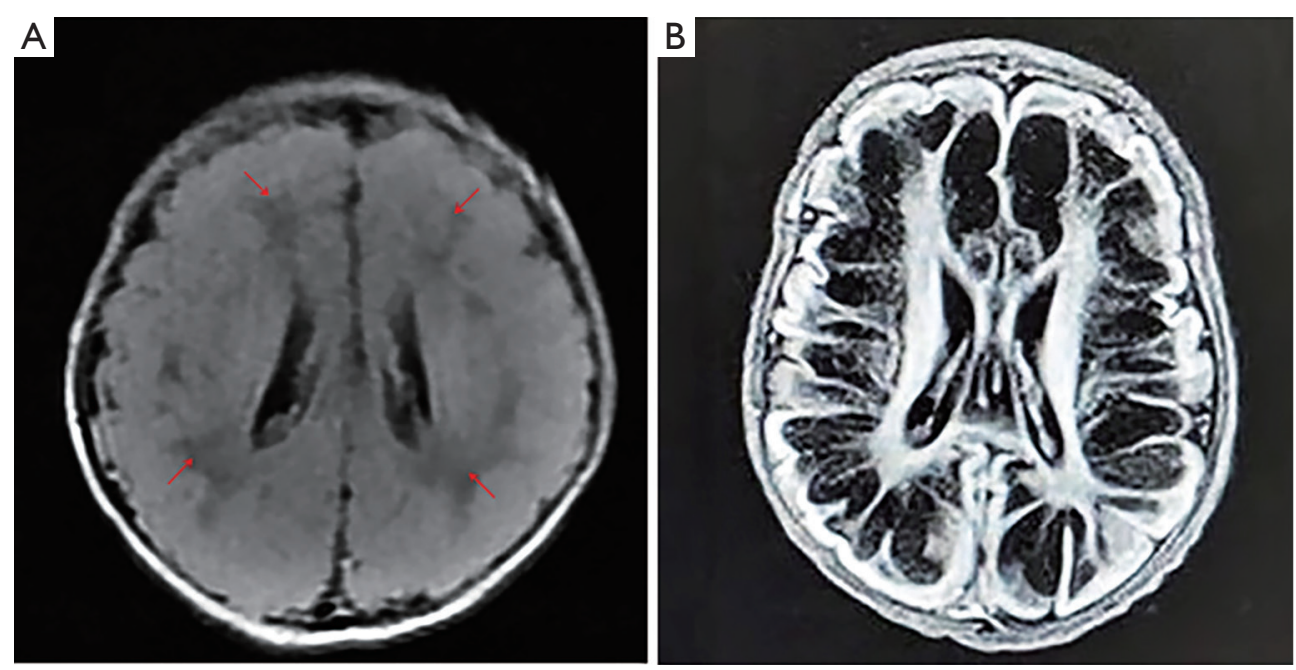

Figure 3 T2 Flair image of brain MRI. (A) At age 3 days from local hospital: there were low-density signals around the lateral ventricle (red arrows). (B) At age 23 days from Shanghai: there were symmetric subcortical cystic white matter changes.

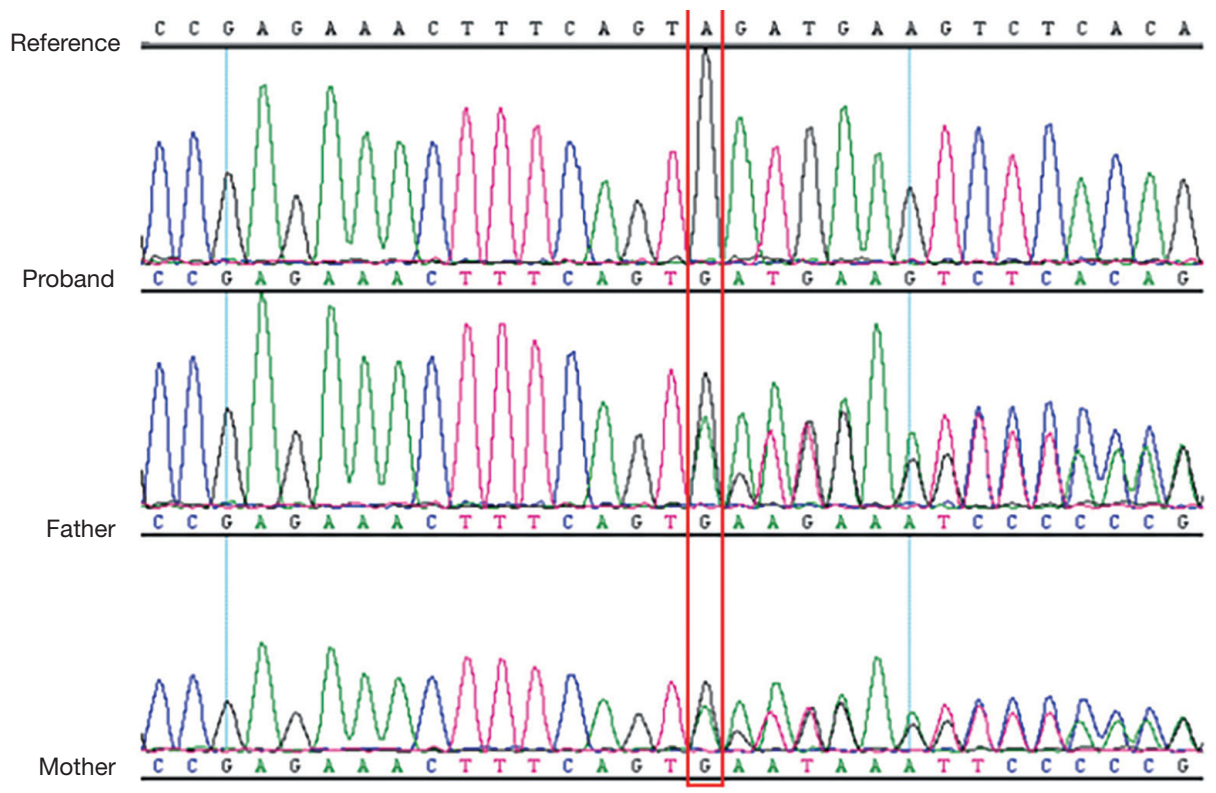

Figure 4 Full exon detection report: the mutation is at exon 4, the 168 base deletion, resulting frameshift mutation.

4, the 168 base deletion, resulting frameshift mutation (Figure 4). This mutation present in the MOCS2 gene was a pathogenic mutation site and was related to Molybdenum cofactor deficiency B This mutation has not been reported in the 1,000 genome population database (GnomAD, 1,000 genome). And the parents were carriers.

\section{Ethical statement}

All procedures performed in study were approved by the ethical review committee of The Second Affiliated Hospital \& Yuying Children's Hospital Affiliated to Wenzhou Medical University and in accordance with the 
Table 1 Review of patients described in the literature who onset newborn of MoCD

\begin{tabular}{|c|c|c|c|c|c|c|}
\hline $\begin{array}{l}\text { Case } \\
\text { no. }\end{array}$ & $\begin{array}{l}\text { Onset } \\
\text { age }\end{array}$ & Clinical features & Laboratory examination & MRI & $\begin{array}{l}\text { Molecular } \\
\text { analysis }\end{array}$ & Reference \\
\hline 1 & Day 3 & $\begin{array}{l}\text { Seizure, feeding } \\
\text { difficulties, hypotonia }\end{array}$ & $\begin{array}{l}\text { Sulfite }(+) \text { and uric } \\
\text { acid } \downarrow \text { in urine }\end{array}$ & $\begin{array}{l}\text { Cerebral atrophy, cystic } \\
\text { encephalomalacia }\end{array}$ & $\begin{array}{l}\text { Exon 1a } \\
\text { 9_14del23 }\end{array}$ & $\begin{array}{l}\text { Hahnewald et al. (6); } \\
\text { Serrano et al. (7) }\end{array}$ \\
\hline 2 & Day 2 & Seizure, poor sucking & Serum uric acid $\downarrow$ & $\begin{array}{l}\text { Cerebral atrophy, multicyclic } \\
\text { encephalomalacia, cerebellar } \\
\text { hypoplasia, brain steam thin }\end{array}$ & $\begin{array}{l}\text { Exon } 2 \\
\text { c. } 130 \mathrm{C}>\mathrm{T}\end{array}$ & Per et al. (8) \\
\hline 4 & Day 3 & $\begin{array}{l}\text { Seizure, facial } \\
\text { dysmorphism }\end{array}$ & $\begin{array}{l}\text { Serum uric acid } \downarrow \text {, } \\
\text { sulfite }(+) \text { in urine }\end{array}$ & Cerebral atrophy, abnormal BG & $\begin{array}{l}\text { Exon } 4 \\
\text { c. } 266 \mathrm{G}>\mathrm{T}\end{array}$ & $\begin{array}{l}\text { Vijayakumar } \\
\text { et al. (10) }\end{array}$ \\
\hline 5 & Day 1 & $\begin{array}{l}\text { Seizure, facial } \\
\text { dysmorphism }\end{array}$ & $\begin{array}{l}\text { Serum uric acid } \downarrow \text {, } \\
\text { sulfite } \uparrow \text { in urine }\end{array}$ & $\begin{array}{l}\text { Cystic encephalomalacia, } \\
\text { abnormal BG }\end{array}$ & $\begin{array}{l}\text { Exon } 4 \\
\text { c. } 266 \mathrm{G}>\mathrm{T}\end{array}$ & $\begin{array}{l}\text { Vijayakumar } \\
\text { et al. (10) }\end{array}$ \\
\hline 7 & Day 2 & Seizure & $\begin{array}{l}\text { Serum uric acid } \downarrow \text {, urine } \\
\text { acid } \downarrow \text {, sulfite }(+) \text { in urine }\end{array}$ & Cerebral atrophy, thin CC & $\begin{array}{l}\text { Exon } 3 \\
\text { c. } 265 \mathrm{~T}>\mathrm{C} / \\
\text { c. } 266 \mathrm{~A}>\mathrm{G}\end{array}$ & Kikuchi et al. (12) \\
\hline 8 & Day 2 & $\begin{array}{l}\text { Seizure, vomiting } \\
\text { developed }\end{array}$ & $\begin{array}{l}\text { Urine acid } \downarrow \text {, urine } \\
\text { S-sulfocysteine } \uparrow\end{array}$ & Thin CC, cerebral dysplasia & $\begin{array}{l}\text { c. } 419 \mathrm{C}>\mathrm{T} / \\
\text { c. } 501+2 \mathrm{delT}\end{array}$ & Edwards et al. (13) \\
\hline 10 & Day 8 & Poor feeding, Seizure & $\begin{array}{l}\text { Serum uric acid } \downarrow \text {, } \\
\text { Sulfite }(+) \text { in urine }\end{array}$ & $\begin{array}{l}\text { Cystic, encephalomalacia } \\
\text { abnormal BG }\end{array}$ & $\begin{array}{l}\text { Exon } 4 \\
\text { c. } 218 \mathrm{~T}>\mathrm{C}\end{array}$ & $\begin{array}{l}\text { Yoganathan } \\
\text { et al. (14) }\end{array}$ \\
\hline 11 & Newborn & $\begin{array}{l}\text { Seizures, feeding } \\
\text { difficulties, facial } \\
\text { dysmorphism }\end{array}$ & Serum uric acid $\downarrow$ & $\begin{array}{l}\text { Cystic, encephalomalacia, } \\
\text { cerebellar hypoplasia }\end{array}$ & $\begin{array}{l}\text { Exon } 1 \mathrm{a} \\
\text { c. }-9 \mathrm{G}>\mathrm{C}\end{array}$ & Arican et al. (15) \\
\hline
\end{tabular}

Helsinki Declaration (as revised in 2013). The Written informed consent was obtained from the patient's parents for publication of this case report and any accompanying images.

\section{Discussion}

There are three steps of molybdenum cofactor synthesis. The MOCS1A and MOCS1B genes encode an enzyme complex that forms cyclic pyranopterin monophosphate (cPMP) from GTP; the products of MOCS2 (MOCS2A and $M O C S 2 B)$ and MOCS3 genes convert CPMP to molybdopterin (MPT); finally, molybdum is inserted to form MoCo by $G E P H$ gene $(1,6)$. So far, the patients with MOCS1A or MOCS1B mutation have been treated with a stable injectable form of cPMP (7), but it is not used in patients with MOCS2 mutation.

The patients with MOCS2 mutation are divided into two forms: early-onset form (beginning during neonatal period), and late-onset form. According to the literature, there are 11 cases of early-onset patient have been previously reported (Table 1) (8-17). Table 1 summarizes the clinical, laboratorial, imagological, genetic findings of these patients. Earlyonset patients always onset within one month after birth, refractory convulsion, feeding difficulty, hypomyotonia and early death, but not all of them have facial dysmorphism (17). The patient in our case is also typically early-onset and with no dysmorphic features. And she is the first Chinese patient reported with symptoms onset in the newborn period. So, it has clinical significance in the future for the diagnosis of patients with similar clinical manifestations in China.

From the laboratory examination of the patient, we just find serumuric acid was undetectable. From the references of neonate with MOCS2 that have been published, laboratory abnormalities include very low levels of serum and urine uric acid, positive urine sulfite test, and increased urine levels of xanthine, hypoxanthine and S-sulfocysteine $(6,18)$. Neonatologists can consider doing further urine 
analyses if similar clinical manifestations are encountered.

The cranial MRI of all the patients onset early has similarities to hypoxic-ischemic encephalopathy (19) and the neurological deterioration develops rapidly. The first MRI of our patient is almost normal, while the MRI on the 23-day-old, shows cystic necrosis of cerebral white matter and thin corpus callosum.

The patient has a homozygous mutation at exon 4, the 168 base deletion, resulting frameshift mutation. And the mutation has not been reported before. We also find the parents of the girl are carriers, although they are not consanguineous.

The injectable cyclic pyranopterin monophosphate (c-PNP) has been effective in MoCoD-A patients, especially in the early stages of disease (20). While there is no effective treatment for the patients with MOCS2 gene mutation so far.

\section{Conclusions}

The patients who diagnosed with MOCS2 in neonate period always show severe seizure, feeding difficulty and low muscle tone, but not all of them have facial features. And the serum uric acid level is low. The MRI of our patient is almost normal in the beginning of the disease, but progresses rapidly, just 20 days later, it shows cavitary changes of white matter. And the disease-causing mutation of MOCS2 in our patient has not been reported before. Unfortunately, there is no treatment for the patients with MOCS2, but we can support genetic counseling for the family.

\section{Acknowledgments}

We want to acknowledge the following two doctors: Jin Wang (Department of Neonatology, Children's Hospital of Fudan University), Yiwei Zhao (Department of Neonatology, Yueqing People's Hospital). Jin Wang and Yiwei Zhao made a lot of work on the writing, revision and finalization of the paper. They provided complete medical history of the infant and diagnosis and treatment ideas. They gave professional advice to the charts in the article, and participated in the integration of references. At the same time, for the editorial department's revision, they also helped to support part of the modification suggestions and professional academic advice. After consultations, all the authors agreed with the acknowledgment to these two doctors.

Funding: None.

\section{Footnote}

Reporting Checklist: The authors have completed the CARE reporting checklist. Available at http://dx.doi.org/10.21037/ tp-20-357

Peer Review File: Available at http://dx.doi.org/10.21037/tp20-357

Conflicts of Interest: All authors have completed the ICMJE uniform disclosure form (available at http://dx.doi. org/10.21037/tp-20-357). The authors have no conflicts of interest to declare.

Etbical Statement: The authors are accountable for all aspects of the work in ensuring that questions related to the accuracy or integrity of any part of the work are appropriately investigated and resolved. All procedures performed in study were approved by the ethical review committee of The Second Affiliated Hospital \& Yuying Children's Hospital Affiliated to Wenzhou Medical University and in accordance with the Helsinki Declaration (as revised in 2013). Written informed consent was obtained from the patient's parents for publication of this case report and any accompanying images.

Open Access Statement: This is an Open Access article distributed in accordance with the Creative Commons Attribution-NonCommercial-NoDerivs 4.0 International License (CC BY-NC-ND 4.0), which permits the noncommercial replication and distribution of the article with the strict proviso that no changes or edits are made and the original work is properly cited (including links to both the formal publication through the relevant DOI and the license). See: https://creativecommons.org/licenses/by-nc-nd/4.0/.

\section{References}

1. Reiss J, Dorche C, Stallmeyer B, et al. Human molybdopterin synthase gene: Genomic structure and mutations in molybdenum cofactor deficiency type B. Am J Hum Genet 1999;64:706-11.

2. Huijmans JGM, Schot R, de Klerk JBC, et al. Molybdenum cofactor deficiency: identification of a patient with homozygote mutation in the MOCS3 gene. Am J Med Genet A 2017;173:1601-6.

3. Reiss J, Lenz U, Aquaviva-Bourdain C, et al. A GPHN 
point mutation leading to molybdenum cofactor deficiency. Clin Genet 2011;80:598-9.

4. Atwal PS, Scaglia F. Molybdenum cofactor deficiency. Mol Genet Metab 2016;117:1-4.

5. Riley DS, Barber MS, Kienle GS, et al. CARE guidelines for case reports: explanation and elaboration document. J Clin Epidemiol 2017;89:218-35.

6. Reiss J, Hahnewald R. Molybdenum cofactor deficiency: Mutations in GPHN, MOCS1, and MOCS2. Hum Mutat 2011;32:10-8.

7. Veldman A, Santamaria-Araujo JA, Sollazzo S, et al. Successful treatment of molybdenum cofactor deficiency type A with cPMP. Pediatrics 2010;125:e1249-54.

8. Hahnewald R, Leimkühler S, Vilaseca A, et al. A novel MOCS2 mutation reveals coordinated expression of the small and large subunit of molybdopterin synthase. Mol Genet Metab 2006;89:210-3. PubMed https://doi. org/10.1016/j.ymgme.2006.04.008

9. Serrano M, Lizarraga I, Reiss J, et al. Cranial ultrasound and chronological changes in molybdenum cofactor deficiency. Pediatr Radiol 2007;37:1043-6.

10. Per H, Gümüş H, Ichida K, et al. Molybdenum cofactor deficiency: clinical features in a Turkish patient. Brain Dev 2007;29:365-368.

11. Sie SD, de Jonge RC, Blom HJ, et al. Chronological changes of the amplitude-integrated EEG in a neonate with molybdenum cofactor deficiency. J Inherit Metab Dis 2010;33:S401-7.

12. Vijayakumar K, Gunny R, Grunewald S, et al. Clinical Neuroimaging Features and Outcome in Molybdenum

Cite this article as: Lin Y, Liu Y, Chen S, Zhu J, Huang Y, Lin Z, Chen S. A neonate with molybdenum cofactor deficiency type B. Transl Pediatr 2021;10(4):1039-1044. doi: $10.21037 /$ tp-20-357
Cofactor Deficiency. Pediatr Neurol 2011;45:246-52.

13. Struys EA, Nota B, Bakkali A, et al. Pyridoxinedependent epilepsy with elevated urinary $\alpha$-amino adipic semialdehyde in molybdenum cofactor deficiency. Pediatrics 2012;130:e1716-9.

14. Kikuchi K, Hamano S, Mochizuki H, et al. Molybdenum cofactor deficiency mimics cerebral palsy: differentiating factors for diagnosis. Pediatr Neurol 2012;47:147-9.

15. Edwards M, Roeper J, Allgood C, et al. Investigation of molybdenum cofactor deficiency due to MOCS2 deficiency in a newborn baby. Meta Gene 2015;3:43-49.

16. Yoganathan S, Sudhakar S, Thomas M, et al. Novel imaging finding and novel mutation in an infant with molybdenum cofactor deficiency: a mimicker of hypoxic ischaemic encephalopathy. Iran J Child Neurol 2018;12:107-12.

17. Arican P, Gencpinar P, Kirbiyik O, et al. The Clinical and Molecular Characteristics of Molybdenum Cofactor Deficiency Due to MOCS2 Mutations. Pediatr Neurol 2019;99:55-9.

18. Hinderhofer K, Mechler K, Hoffmann GF, et al. Critical appraisal of genotype assessment in molybdenum cofactor deficiency. J Inherit Metab Dis 2017;40:801-11.

19. Appignani BA, Kaye EM, Wolpert SM. CT and MR appearance of the brain in two children with molybdenum cofactor deficiency. AJNR Am J Neuroradiol 1996;17:317-20.

20. Schwahn BC, Van Spronsen FJ, Belaidi AA, et al. Efficacy and safety of cyclic pyranopterin monophosphate substitution in severe molybdenum cofactor deficiency type A: a prospective cohort study. Lancet 2015;386:1955-63. 